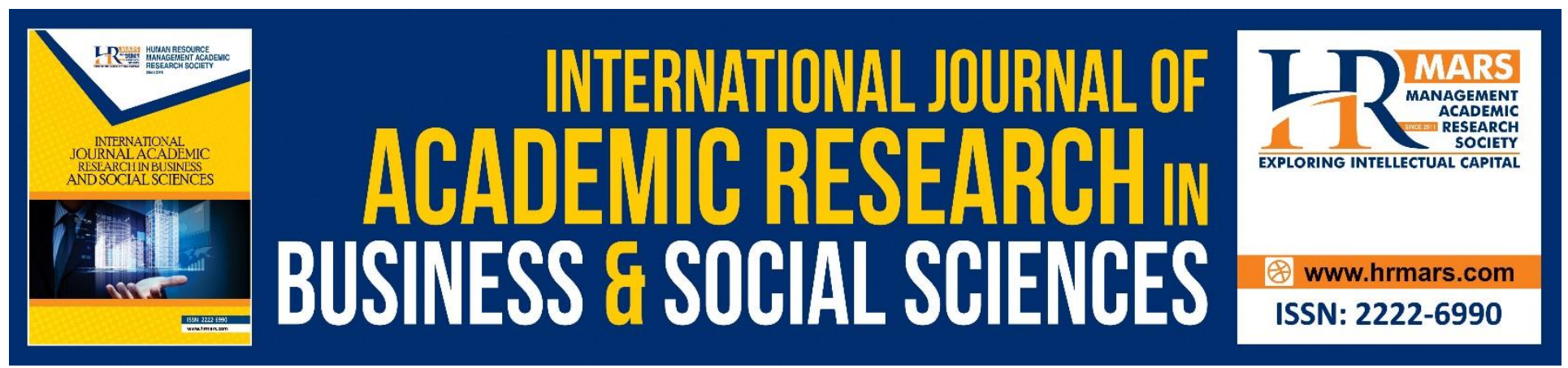

\title{
Influence of Internal Audit on Effective Financial Management at the Cape Coast Metropolitan Assembly
}

\section{Nuhu Alhassan}

To Link this Article: http://dx.doi.org/10.6007/IJARBSS/v8-i9/4673

DOI: $\quad 10.6007 /$ IJARBSS/v8-i9/4673

Received: 07 August 2018, Revised: 27 August 2018, Accepted: 23 Sept 2018

Published Online: 15 October 2018

In-Text Citation: (Alhassan, 2018)

To Cite this Article: Alhassan, N. (2018). Influence of Internal Audit on Effective Financial Management at the Cape Coast Metropolitan Assembly. International Journal of Academic Research in Business and Social Sciences, 8(9), 977-987.

\section{Copyright: (c) 2018 The Author(s)}

Published by Human Resource Management Academic Research Society (www.hrmars.com) This article is published under the Creative Commons Attribution (CC BY 4.0) license. Anyone may reproduce, distribute, translate and create derivative works of this article (for both commercial and non-commercial purposes), subject to full attribution to the original publication and authors. The full terms of this license may be seen at: http://creativecommons.org/licences/by/4.0/legalcode

Vol. 8, No. 9, September 2018, Pg. 977 - 987

Full Terms \& Conditions of access and use can be found at http://hrmars.com/index.php/pages/detail/publication-ethics 


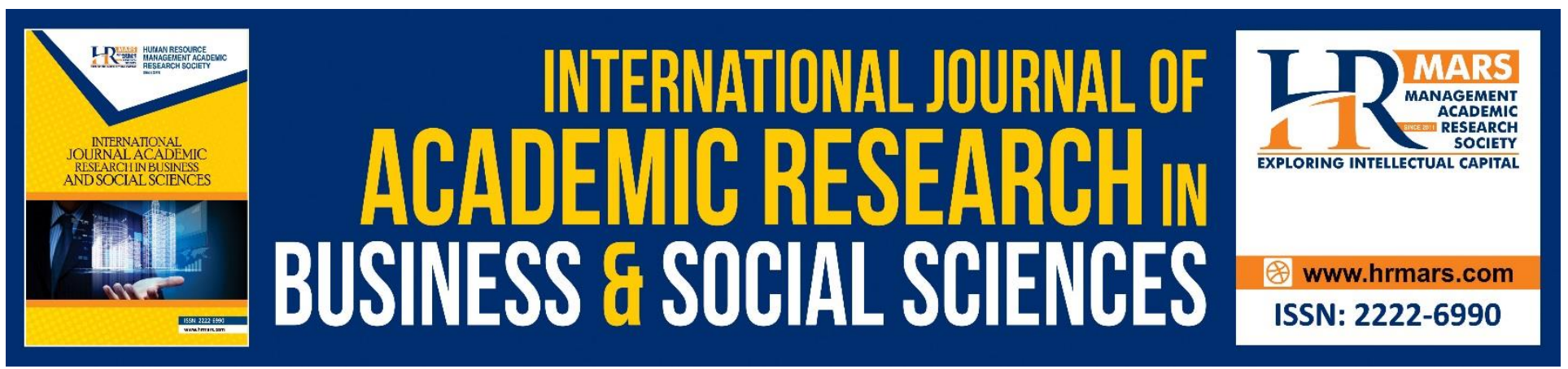

\title{
Influence of Internal Audit on Effective Financial Management at the Cape Coast Metropolitan Assembly
}

\author{
Nuhu Alhassan \\ Directorate of Internal Audit, University of Cape Coast, Ghana \\ Email: Nuhu.alhassan@ucc.edu.gh
}

\section{Abstract}

The purpose of the study was to investigate the influence of internal audit on the effectiveness of financial management at the Cape Coast Metropolitan Assembly (CCMA), Central Region of Ghana. The correlational research design was used for the study. The study population was 123 while the sample size for the study was 100 . The lottery method of simple random sampling procedure was used to select the respondents. Questionnaire was used to collect data. The Cronbach alpha reliability coefficient of the questionnaire was 0.851 , which was deemed appropriate and significant. The data were analysed using inferential statistics. The findings of the study revealed that determinants of internal audit (independence of internal audit, internal controls, professional competence and internal audit standards) have statistically significant influence on effective financial management at the CCMA. It is recommended to government through the Ministry of Local Government and Rural Development, and the management of the various MMDAs to ensure that internal auditors within the various MMDAs continue to update themselves with the changing times and technologies and sharpen their skills. Also, they should ensure that internal auditors within the assemblies are independent, qualify and act professional such that they will not be under the control of the Chief Executive but part of the management team.

Keywords: Effective Financial Management, Internal Audit, Internal Controls, Local Government

\section{Introduction}

Historically, the concept of internal audit has served as a simple administrative procedure comprised mainly of checking documents, counting assets, and reporting to board of directors, management or external auditors. In recent times, however, a combination of different forces has led to a quiet revolution of the profession. The concept of internal audit refers to an independent, objective assurance and consulting activity designed to add and improve an organisation's operations (Dawuda, 2014). It helps an organisation to accomplish its objectives by bringing a systematic, 
INTERNATIONAL JOURNAL OF ACADEMIC RESEARCH IN BUSINESS AND SOCIAL SCIENCES Vol. 8, No. 9, Sept. 2018, E-ISSN: 2222-6990 @ 2018 HRMARS

disciplined approach to evaluate and improve the effectiveness of risk management control, and governance processes (Musa, 2015).

Both public and private organisations have to demonstrate accountability in the use of shareholders or citizens money and efficiency in the delivery of services. Organisations, especially public ones, now demand great competency and professionalism from internal audit, and scarce resources must be deployed more efficiently to minimise and manage risks. The transition from merely ensuring compliance with rules and regulations to truly delivering added value requires more than just organisational changes. In many public institutions staff are poorly paid and unmotivated, ethical standards are weak, and governance practices are ineffective leading to asset mismanagement (Obert \& Munyunguma, 2014).

The need for accountability and good governance in various countries today is solving issues relating to globalisation, transparency, integrity and improvement in government delivery services. This has however led to the increase of internal audit function in the various public sector institutions. Currently the internal audit function is becoming one of the essential aspects of good governance and management both in the private and the public sectors (Kotoka, 2015). However in the local government sector, due to their response to diverse stakeholder there is the need to ensure the credibility of the internal audit functions. Also, there is the need to have an effective internal audit function in all public sector institutions in modern governance.

Every democratic country needs to be accountable in the effective use of public monies and the need to provide effective, efficient and economical service delivery. This objective can be achieved by applying internal audit function in order to ensure value for money in all projects within the local government sector. In addition, this major mechanism can be used to control and use of scarce resources in the corporate organisations. However in a more complex and large systems require greater competiveness, and therefore the need for professional internal audit function. Therefore, it is not surprising that Ghana and other developing countries are focusing on improving its financial management at the local government level through effective internal auditing (Kwanbo as cited in Kotoka, 2015).

According to Kotoka (2015), government of Ghana through act of parliament has established the Internal Audit Agency Act (IAA Act 2003, Act 658). This is to facilitate and give quality assurance to activities of the internal audit unit in the various public institutions including Metropolitan, Municipal, and District Assemblies (MMDAs). Three strategies have being formulated to help improve the activities of the unit in the various public organisations. They are professional practice framework for key documents and templates, human resource development which provides recruitment, training and development for its members in order to apply internal audit standards, procedures and techniques efficiently, and quality assurance and improvement which addresses issues of continuous improvement in the discharge of internal audit duties. The success of every internal auditor depends on his contribution towards the development of the institution. It is therefore important that internal auditors provide the necessary and relevant information to management, to enable them take good decision toward the achievement of its goals and objectives.

The discussion so far shows that effectiveness and efficiency of financial management within MMDAs is dependent on the employees in the organisation, especially the auditors. Therefore there is the need to ensure effective internal auditing in MMDAs. According to Adeyemi, Akindele and Agesin (2012), internal audit unit plays an important role in modern corporate governance in public 
offices. It is therefore important for management to ensure that there is an effective internal audit function since is received a lot attention in recent years due to diverse reasons. Some of the reasons for internal audit include, it helps in internal control risk management, giving constructive criticism and recommendation which will improve efficiency and effectiveness, information asymmetry is reduced, and serving as an internal assurance in business and financial reporting of corporations (AlMatari, Al-Swidi \& Fadzil, 2014; Ussahawanitchakit \& Intakhan, 2013). If MMDAs want the best in effective quality financial management there is the need for them to protect and enhance the functions of internal audit.

\section{Statement of the Problem}

There are a lot of negative perceptions and misconceptions about internal audit in the public sector, especially at the local government level (Aikins, 2011). These are caused by several factors such as fear of loss of jobs, lack of knowledge about the functions of audit and fear of the unknown. Some negative perceptions are also caused by people who are after personal gain from government or public resources (Adeyemi et al., 2012). According to Adeyemi et al., they feel audit will uncover their secrets. So they want to discredit audit as much as possible so that the audit report will not be credible. These negative perceptions have an influence on the performance of the internal audit function. According to Dawuda (2014), most MMDAs in Ghana do not have an effective internal audit function. Those that have effective internal audit unit, look down upon it. They do not tap from the benefits that accrue from having internal audit.

The Cape Coast Metropolitan Assembly (CCMA) internal audit unit and the auditor face a lot of challenges, to which to some extend hinder the credibility of their work (CCMA, 2016). Most employees and unit/departmental heads within the metropolitan assembly hardly see them as partners in the development agenda of the assembly but fault-finders which do not enable them execute their work effectively. Sometimes the necessary contribution and support which will help internal auditors are woefully inadequate because most managers see them as a threat rather than co-partner to the assembly.

According to the Public Account Committee of Parliament of Ghana (2016), there are still reported cases of embezzlement, corruptions, financial maleficence and irregularity in the MMDAs after the enactment of the act. The Public Account Committee which investigates into the activities of government sector gives us an indication that controls in the management of government resources are poorly managed at the local government level. This explains the reason why a lot of activities or transactions in the MMDAs levels do not go through the necessary authorisation, approval, goals and checks. The study therefore seeks to find out the influence of internal audit on the effective financial management of public institutions at the local government level, focusing on the CCMA, Central Region of Ghana.

\section{Objective of the Study}

The main objective of the study was to investigate the influence of internal audit on the effectiveness of financial management at the CCMA, Central Region of Ghana. The specific objectives of the study were to:

1. Examine the relationships between independence of internal audit, internal audit standards, internal controls, professional competence and effective financial management at the CCMA. 
2. Determine the influence of internal audit on effective financial management at the CCMA.

\section{Significance of the Study}

Government of Ghana, through the local government ministry and other agencies have establish policies, plans, procedures, laws and regulation which have significant effects to the day to day running of MMDAs. It is therefore the duty of the internal auditors to ensure management complies with the said rules and regulations to safeguard government chest, and prevent fraud and corruption at the local level. Internal auditors are also expected to add value to the operations of public organisations and help reduce administrative cost (Aikins, 2011). This study would help MMDAs and the CCMA in particular to appreciate and know the role of internal auditors and their relevant in achieving effective financial management at the local government level.

It will also enable the governing body, and audit committee of the assemblies and any other organisations in the public sector, to be aware of the importance use of internal audit, and gives insights into how they use the internal audit service most efficiently to ensure that there is effective financial management at the assemblies. Another important significance of this study is that, it would guide the internal auditors in their professional work. It emphasises the need for internal auditors to approach their work with professionalism, integrity, confidentiality, good ethical behaviour, competencies in order to contribute meaningfully to the realisation of the objectives of the assembly.

\section{Scope of the Study}

The study was delimited to the permanent staff of the CCMA. The study was further delimited to constructs or variables such as independence of internal audit, effective financial management, internal audit standards, internal controls, and professional competence of the internal auditors.

\section{Conceptual Framework}

A careful analysis of the review of literature suggests that internal audit is determined by many factors, and these factors can conceptually be grouped into four independent variables as depicted in Figure 1. These variables pooled together formed the internal audit construct which is the independent variable of the model and the study for that matter. The review indicates that effective financial management on the part of organisations are spearheaded by recognised and independent internal audit unit/department. The dependent variable is effective financial management which was measured using five indicators as indicated in the figure. 


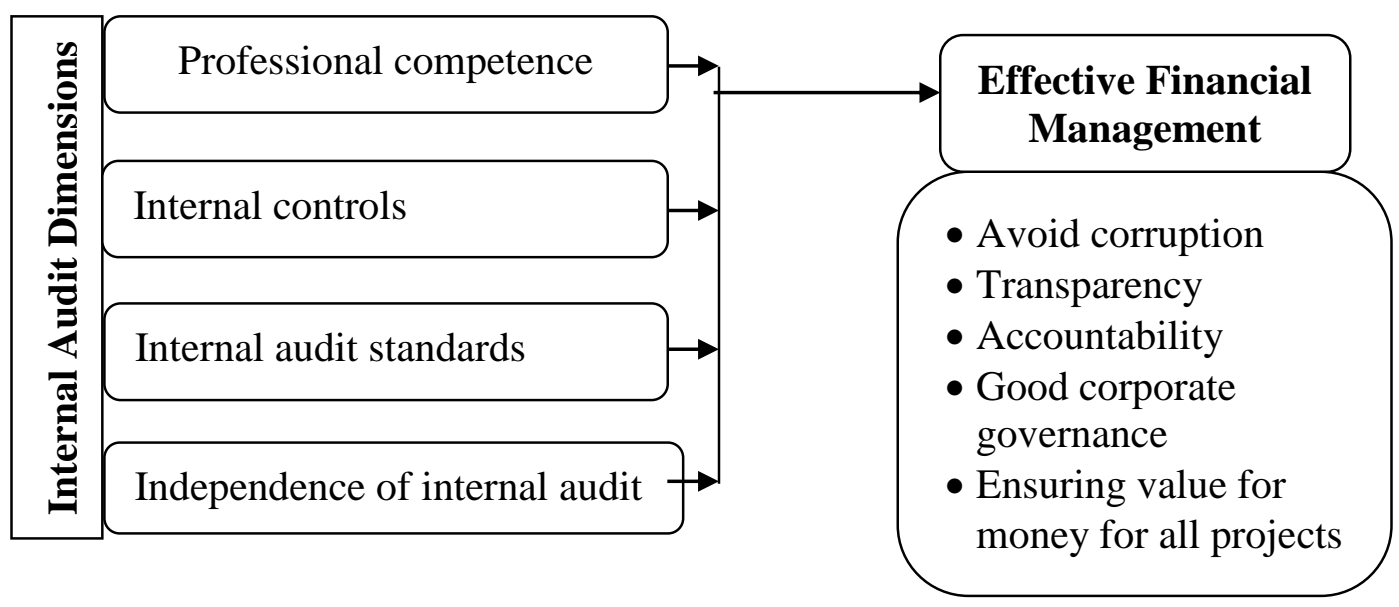

Figure 1: Influence of Internal Audit on Effective Financial Management

Source: Adapted from Al-Matari et al., 2014

The general argument of the study is that, if the various internal audit units/departments within the various MMDAs, especially that of CCMA, are able to ensure that they exhibit professional competence, internal controls, internal audit standards, and independence of internal audit, it may lead to improvement in the finances of the assembly. This can be achieve if government and management of the assemblies support the internal audit unit in achieving and ensuring these four dimensions are achieve. With these variables in place, staff of the assembly and the citizens for that matter are likely to perceive the work of the internal audit unit positively which will in turn boost the confident and commitment level of the auditors. These dynamics in the long run may results in increase in the finances of the assembly through effective financial management.

\section{Methodology}

The study adopted the quantitative approach because it ensured greater objectivity and accuracy of results. Also, the researcher employed the use of correlational study design in the study. The study chose the staff of the CCMA as its population because they are the most appropriate group of elements to express their views on internal audit and its influence on effective financial management at the assembly. Records from the assembly as at the end of the second quarter of 2017 show that currently there are 123 staff in the assembly (CCMA, 2016).

\section{Sample and Sampling Procedure}

The sample size for the study was 100 . This sample was determined based on Krejcie and Morgan's (1970) recommended table for determining a sample size from a given population. The lottery method of simple random sampling procedure which is one of the probability sampling techniques was used to select the sampled respondents. Using this procedure, the researcher was allowed to have access to the offices and the premise of the assembly while giving questionnaires to staff based on the lottery method of random sampling. The personnel unit of the assembly were contacted for data regarding the staff strength of the assembly. This was used to design a sample frame for the study. 123 pieces of paper were cut and put in an opaque polythene bag. These papers were made up of 100 'YES' and 23 'NO'. Based on the guidance of the sample frame, staff of the 
INTERNATIONAL JOURNAL OF ACADEMIC RESEARCH IN BUSINESS AND SOCIAL SCIENCES Vol. 8, No. 9, Sept. 2018, E-ISSN: 2222-6990 @ 2018 HRMARS

assembly were asked to select from the bag without looking into it. Those that picked papers that were marked 'YES' were given questionnaires while those that picked 'NO' were not given. The process of selection continued until the required sample size (100) was obtained.

\section{Instrumentation}

The study employed the use of the questionnaire in the collection of data since all staff of the assembly were literate. The questionnaire was pre-tested at the Komenda-Edina-Eguafo-Abrem (KEEA) Municipality, also in the Central Region of Ghana. This municipality was chosen because of its similar characteristics with CCMA and also its proximity to the researcher. The Cronbach alpha reliability coefficient obtained from the questionnaire was 0.851 which was deemed appropriate (Yates, 2014).

\section{Data Collection Procedures and Analysis}

The main data collection started from 13 ${ }^{\text {th }}$ June, 2017 and was completed on July 15, 2017. On the first day, the researcher introduced himself to the management and staff of the assembly even though an introductory letter had been sent earlier to the management of the assembly. After that, the researcher was asked to stand in front of the main and central entrance to the assembly to administer all the questionnaires at the stipulated time. However, in relation to some of the respondents, the questionnaire was administered at their offices. For a respondent to be selected, the researcher first of all approaches him or her personally to explain the purpose of the study and whether he or she would like to participate. All those that were contacted randomly were exposed to the lottery method of selection. Each of the respondents contacted were asked to pick a paper from the opaque polythene bag that the researcher was holding which comprised of 123 equal pieces of paper where 23 were marked 'No' whilst 100 others were marked 'Yes'. This gave each respondent an equal chance of being selected.

Some of the respondents, especially the junior staff, who could not comprehend some of the statements of the instrument were assisted to answer or respond to the items. Fortunately for this study, most of the respondents were literate and they returned the answered questionnaire on the same day. Out of the 100 questionnaires given out, 97 completed questionnaires were retrieved, representing 97.0 percent response rate.

The data collected were first sorted, coded and processed using the Statistical Product and Service Solutions (SPSS) Version 19.0. Specifically, data on the first and second specific objectives of the study were analysed using Pearson product moment correlation and linear multiple regression analyses respectively. These statistical tools were used because the study was correlation in nature and also was quantitative in nature. Quite apart from that the responses to the items in the questionnaire were measured using unilinear scale.

\section{Results and Discussion}

The first specific objective of the study focused on the relationship that exists between the four determinants of internal audit and the effectiveness of the assembly's financial management. In tackling this objective, the study formulated multiple items to elicit data on each of the main variables. Responses to these items were measured using four-point unilinear scale such that one (1) represents the least agreement to the issues while four (4) represents the strongest agreement to 
INTERNATIONAL JOURNAL OF ACADEMIC RESEARCH IN BUSINESS AND SOCIAL SCIENCES Vol. 8, No. 9, Sept. 2018, E-ISSN: 2222-6990 @ 2018 HRMARS

the issues. These items were pooled together to form the main variables. The results are presented in Table 1.

Table 1: Relationship between Determinants of Internal Audit and Effective Financial Management at CCMA

\begin{tabular}{lcccc}
\hline & & & \multicolumn{2}{c}{ Effective Financial Management } \\
Variables & Mean & Std. Dev. & Correlation coefficient $(r)$ & Sig. \\
\hline Professional competence & 2.704 & 1.168 & $0.566^{* *}$ & 0.000 \\
Internal controls & 3.517 & 0.901 & $0.641^{* *}$ & 0.000 \\
Internal audit standards & 2.827 & 1.069 & $0.432^{* *}$ & 0.000 \\
Independence of internal audit & 3.021 & 0.852 & $0.682^{* *}$ & 0.000 \\
Effective financial management & 3.297 & 0.702 & 1 & \\
\hline
\end{tabular}

Source: Field Data, $2017 \quad * * p<0.01 \quad(N=97)$

The results in Table 1 shows that all the four determinants of internal audit were perceived positively (Mean scores $>2.5$ ) by the respondents. However, internal controls (Mean $=3.517, \mathrm{SD}=$ 0.901 ) and independence of internal audit (Mean $=3.021, \mathrm{SD}=0.852$ ) were the most positively perceived determinants by the respondents. This mean that staff of the CCMA are more concern with the internal controls put in place by management of the assembly and the independence of internal audit unit. The findings further show that independence on the part of the internal audit unit is the essence of auditing. An internal auditor must be independent of both the personnel and operational activities of an organisation. Otherwise, the integrity of the auditor's opinions, conclusions and recommendations would be suspect.

Furthermore, respondents' positive perception on the internal controls of the assembly shows that controls audits in the assembly provide assurance that controls are working. However, they do not necessarily detect fraud or corruption. Internal controls audit objectives relate to management's plans, methods, and procedures used to meet the organisation's mission, goals, and objectives. The findings are in line with the submission of Dawuda (2014) who indicated that the existence of control is very crucial especially under today's condition with severe competition which place premium on reliable services, on consideration of cash, on realisation of capital assets and manpower and on other reduction costs. That is why within MMDAs, especially that of CCMA, cash receipts as well as cash disbursements bear fairly strong controls attributed to the fact that the government accounting system is still in operation. However, the internal auditors in most MMDAs are being underutilised as they are usually charged with the responsibility of performing routine control checks which are also performed by the examination section. This to some extent has led to duplication of efforts and down playing of the internal auditor's effective role at the CCMA.

Table 1 further show that independence of internal audit $(r=0.682, p<0.01)$, internal controls $(r=0.641, p<0.01)$, and professional competence $(r=0.566, p<0.01)$ are strongly related to staff view on effective financial management of the assembly positively. Similarly, internal audit standards has a statistically significant positive relationship with staff perception on the effectiveness of the assembly's financial management $(r=0.432, p<0.01)$. The association between the four determinants of internal audit and staff view on the effectiveness of the assembly's financial management was strong and positive. This means that as internal auditors of the assembly ensure 
INTERNATIONAL JOURNAL OF ACADEMIC RESEARCH IN BUSINESS AND SOCIAL SCIENCES Vol. 8, No. 9, Sept. 2018, E-ISSN: 2222-6990 @ 2018 HRMARS

that they exhibit their professional competence and also follow the standards within internal audit while management of the assembly also ensure that there is appropriate internal controls and independence of internal audit unit; there is strong likelihood that the assembly will experience an effective financial management system.

The findings corroborate with the submissions of Obert and Munyunguma (2014) who avers that there is a relationship between internal audit and effective financial management within an organisation. Furthermore, the results may mean that financial performance requires appropriate internal audit practices to enhance efficiency. The findings are consistent with the comments of Dawuda (2014) who posited that internal audit standards, independence of internal audit, professional competency and internal control had a positive relationship with good corporate governance in the public sector.

The second specific objective of the study examined the influence of internal audit on effective financial management at the CCMA. The four determinants of internal audit were treated as independent variables while effective financial management was the dependent variable. Results of the analysis are shown in Table 2 . The results show that all the entered independent variables, that is determinants of internal audit, were statistically significant contributors of effective financial management in the CCMA. As contained in the table, the variables that contributed meaningfully to effective financial management in the assembly, in order of importance, are independence of internal audit $(\beta=0.429, p<0.01)$, internal controls $(\beta=0.325, p<0.01)$, professional competence $(\beta=0.183$, $p<0.01)$, and internal audit standards $(\beta=0.090, p<0.05)$. Independence of internal audit and internal controls were the strongest determinants of internal audit that influenced significantly to effective financial management at the CCMA (42.9\% and $32.5 \%$ respectively).

Table 2: Influence of Internal Audit on Effective Financial Management

\begin{tabular}{|c|c|c|c|c|c|c|c|}
\hline \multirow[b]{2}{*}{ Variables } & \multicolumn{2}{|c|}{$\begin{array}{l}\text { Unstandardised } \\
\text { Coefficients }\end{array}$} & \multirow{2}{*}{$\begin{array}{l}\text { Standardised } \\
\text { Coefficients } \\
\text { Beta }\end{array}$} & \multirow[b]{2}{*}{$\mathrm{t}$} & \multirow[b]{2}{*}{ Sig. } & \multicolumn{2}{|c|}{$\begin{array}{c}\text { Collinearity } \\
\text { Statistics }\end{array}$} \\
\hline & B & SE & & & & Tol. & VIF \\
\hline Internal controls & 0.195 & 0.050 & $0.325 * *$ & 3.906 & 0.000 & 0.526 & 1.902 \\
\hline Internal audit standards & 0.070 & 0.071 & $0.090 *$ & 2.589 & 0.032 & 0.439 & 2.279 \\
\hline Independence of internal audit & 0.282 & 0.054 & $0.429 * *$ & 5.180 & 0.000 & 0.529 & 1.890 \\
\hline Professional competence & 0.151 & 0.055 & $0.183 * *$ & 2.737 & 0.007 & 0.813 & 1.230 \\
\hline Constant & & & 1.187 & & & & \\
\hline $\mathrm{R}$ & & & 0.820 & & & & \\
\hline R Square & & & 0.673 & & & & \\
\hline Adjusted R Square & & & 0.651 & & & & \\
\hline Source: Field Data, 2017 & \multicolumn{3}{|c|}{$* * p<0.01 ; * p<0.05$} & \multicolumn{2}{|c|}{$(N=97)$} & & \\
\hline \multicolumn{8}{|c|}{ Dependent Variable: Effective Financial Management } \\
\hline \multicolumn{8}{|c|}{ Where Tol. = Tolerance, $\mathrm{SE}=$ Standard Error } \\
\hline \multicolumn{8}{|c|}{$\begin{array}{l}\text { The findings are in line with the comments of Ussahawanitchakit and Intakhan (2013) who } \\
\text { aver that for an organisation to achieve effective financial management, management of the } \\
\text { organisation must ensure that internal audit unit is objective and impartial. This means that the unit } \\
\text { should perform its activity free of doubts and interference, and that it should be responsible for }\end{array}$} \\
\hline
\end{tabular}


performs its activities in accordance with the due principles of internal audit. The findings further support the call made by Al-Matari et al. (2014) that management of organisations must ensure that controls audits are designed to ensure appropriate controls over systems and also software are in place to ensure that internal controls and internal checks are functioning as designed. According to Al-Matari et al. (2014), these interventions will help enhance the effectiveness of the organisation's financial management and finances as a whole. Controls audits provide assurance that controls are working, but they do not necessarily detect fraud or corruption.

The total contribution of the independent variables (internal controls, internal audit standards, independence of internal audit, and professional competence) to the variance in the dependent variable (effective financial management) was 0.673 with an adjusted $R^{2}$ of 0.651 . This means that internal audit influenced or explained about 67.3 percent of the variance in the assembly's effective financial management. Therefore, internal audit has a statistically significant influence on the effectiveness of the CCMA financial management.

The findings are congruent with that of Musa (2015) who found out in his study that a unit increase in internal audit standards would lead to increase in financial performance of commercial banks in Indonesia, a unit increase in independence of internal audit would lead to increase in financial performance of commercial banks, a unit increase in professional competency would lead to increase in financial performance of commercial banks and further unit increase in internal control would lead to increase in financial performance of commercial banks. One therefore, needs to acknowledge the role of internal audit department/unit to the establishment of internal controls which have an effect on the finances of the institutions.

\section{Limitations}

The research was faced with limited access to literature information on the study institution due to unavailability of well-resourced data or library facilities at the assembly. Again, the study assumed that the selected staff of the assembly had sufficient knowledge and understanding of the concepts, issues and what is expected of them to answer the items in the questionnaire accurately and truthfully, but this was not verified. In addition, the findings and conclusions of the study may not be projected for the future since issues related to internal audit and effective financial management keep changing with time.

\section{Conclusions}

Based on the findings that emerged, the study concludes that meaningful variation in the effectiveness of the assembly's financial management are cause by changes in internal audit standards, independence of internal audit, professional competency and internal control. This shows that changes in the effectiveness of the assembly's financial management could be accounted for by dynamics in internal audit standards, independence of internal audit, professional competency and internal control. The study also established that there was a strong positive relationship between internal audit and the effectiveness of financial management of the assembly. The conclusion then is that a unit increase in determinants of internal audit would lead to increase in the effectiveness of the assembly's financial management. Therefore, internal auditors of the various MMDAs must be independent of both the personnel and operational activities of the assemblies. 
INTERNATIONAL JOURNAL OF ACADEMIC RESEARCH IN BUSINESS AND SOCIAL SCIENCES

Vol. 8, No. 9, Sept. 2018, E-ISSN: 2222-6990 @ 2018 HRMARS

\section{References}

Adeyemi, O. O., Akindele, S. T., \& Agesin, B. (2012). Review: Institutionalising the culture of accountability in local government administration in Nigeria. African Journal of Political Science and International Relations, 6(4), 81-91.

Aikins, S. K. (2011). An examination of government internal audits' role in improving financial performance. Public Finance and Management, 11(4), 306-337.

Al-Matari, E. M., Al-Swidi, A. K., \& Fadzil, F. H. B. (2014). The effect of the internal audit and firm performance: A proposed research framework. International Review of Management and Marketing, 4(1), 34-41.

Cape Coast Metropolitan Assembly [CCMA] (2016). Annual report: 2015/2016 financial year. Unpublished report, Cape Coast Metropolitan Assembly, Ministry of Local Government and Rural Development, Cape Coast, Ghana.

Dawuda, A. (2014). A study into the effectiveness of the internal audit units in the public sector in promoting good corporate governance: The case of the metropolitan, municipal and district assemblies in the Northern region of Ghana. Unpublished master's thesis, Department of Accounting and Finance, School of Business, University of Cape Coast, Cape Coast.

Kotoka, A. F. (2015). Assessing the level of compliance with the public procurement Act 2003 (Act 663) in public entities in Ashanti Region of Ghana. Unpublished master's thesis, Institutte of Distance Learning, Kwame Nkrumah University of Science and Technology, Kumasi.

Krejcie, R. V., \& Morgan, D. W. (1970). Determining sample size for research activities. Educational and Psychological Measurement, 30(3), 607-610.

Musa, A. (2015). Impact of risk based audit on financial performance of commercial banks in Indonesia. Asian Review of Business Research, 13(1), 26-37.

Obert, S., \& Munyunguma, I. N. (2014). Internal audit perceptions and their impact on performance of the internal audit function. IOSR Journal of Business and Management, 16(5), 81-85.

Public Account Committee, Parliament of Ghana. (2016). Recommendations on auditor general's report for 2010/2011: Final draft. Accra: Government of Ghana.

Ussahawanitchakit, A., \& Intakhan, A. (2013). Audit professionalism, audit independence and audit effectiveness of CPAs in Thailand. International Journal of Business Research, 11(2), 1-11.

Yates, S. J. (2014). Doing social science research (2 ${ }^{\text {nd }}$ ed.). London: Sage Publications. 